Artikel Riset

DOI : 10.33751/jf.v10i1.2072
Fitofarmaka Jurnal Ilmiah Farmasi

Vol.10, No.1, Juni $2020: 84-96$

p-ISSN : 2087-9164 e-ISSN : 2622-755X

\title{
FORMULASI DAN UJI ANTI BAKTERI SEDIAAN GEL \\ EKSTRAK DAUN MANGGA ARUMANIS (Mangifera indica L.) SEBAGAI ANTI BAKTERI Staphylococcus aureus DAN Propionibacterium acnes
}

\author{
'Prasetyorini Djarot, ${ }^{2)}$ Isna Diana, ${ }^{3)}$ Dwi Indriati \\ 1) Program Studi Biologi, FMIPA, Universitas Pakuan \\ 2,3) Program Studi Farmasi, FMIPA, Universitas Pakuan \\ email: prasetyorini@unpak.ac.id
}

Diterima : 4 Juni 2020

Direvisi : 29 Juni 2020

Disetujui : 30 Juni 2020

\begin{abstract}
ABSTRAK
Penelitian ini dilatarbelakangi oleh masalah kelainan kulit berupa jerawat yang salah satu penyebabnya adalah bakteri $S$. aureus dan $P$. acnes. Beberapa hasil penelitian menyatakan bahwa daun mangga mengandung senyawa bioaktif yang potensial sebagai antibakteri seperti flavanoid, saponin, dan mangiferan. Perlu diteliti potensi ekstrak daun mangga dalam sediaan gel sebagai obat antijerawat. Tujuan penelitian ini adalah membuat formula sediaan gel ekstrak daun mangga arumanis berpotensi sebagai antibakteri $S$. aureus dan $P$. acnes dan memenuhi syarat farmaseutika. Metode ekstraksi yang digunakan adalah maserasi dengan pelarut etanol 70\%. Pengujian KHM dilakukan dengan metode dilusi agar, pengujian LDH menggunakan metode difusi sumuran. Sediaan gel dibuat dengan tiga konsentrasi penambahan ekstrak daun mangga arumanis yaitu formula F1 (20\%), F2 (25\%) dan F3 (30\%). Basis gel digunakan sebagai kontrol negatif dan acnol gel sebagai kontrol positif. Hasil penelitiaan menunjukkan ekstrak etanol $70 \%$ daun mangga memiliki nilai KHM sama untuk bakteri $S$. aureus maupun $P$. acnes yaitu pada konsentrasi $20 \%$. Gel Formula 1 memiliki LDH terhadap bakteri $S$. aureus dan $P$. acnes masing-masing 3,83 $\pm 0,76 \mathrm{~mm}$ dan 1,83 $\pm 0,28 \mathrm{~mm}$; Formula 2 memiliki LDH terhadap $S$. aureus dan $P$. acnes sebesar $6,83 \pm 0,28 \mathrm{~mm}$ dan $2,83 \pm 0,57 \mathrm{~mm}$; Formula 3 memiliki LDH terhadap $S$. aureus dan $P$. acnes masing-masing sebesar 9,33 $\pm 0,57 \mathrm{~mm}$ dan $3,00 \pm 0,5 \mathrm{~mm}$. Dari penelitian ini, dapat disimpulkan bahwa gel Formula 3 yang mengandung 30\% ekstrak daun mangga adalah formula yang paling efektif terhadap $S$. aureus dengan Zona Penghambatan tertinggi 9,33 mm.
\end{abstract}

Kata kunci: Ekstrak daun mangga arumanis, gel anti bakteri, Staphylococcus aureus, Propionibacterium acnes

\section{FORMULATION AND ANTI-BACTERIAL TEST OF ARUMANIS MANGGO LEAF EXTRACT GEL (MANGIFERA INDICA L.) AS ANTI-BACTERIA Staphylococcus. aureus and Propionibacterium ACNES}

\begin{abstract}
This research is motivated by the problem of skin disorders in the form of acne which are caused by the bacteria Staphylococcus aureus and Propionibacterium acnes. Previous research suggest that mango leaves contain potential bioactive compounds as antibacterial such as flavonoids, saponins, and mangiferan. It is necessary
\end{abstract}


to study the potential of mango leaf extract in gel form as an anti-acne drug. The purpose of this study was to formulated arumanis mango leaf extract gel as an antibacterial against $S$. aureus and $P$. acnes which meets pharmaceutical requirements. The extraction method used was maceration with $70 \%$ ethanol solvent. The MIC test was conducted using the solid dilution method, inhibition zone was tested using well diffusion method. Gel preparations was made with addition of arumanis mango leaf extract namely formula F1 (20\%), F2 (25\%), F3 (30\%). The basis gel was used as a negative and acnol gel as a positive control. The results of the research showed that the $70 \%$ ethanol extract of mango leaf gel had the same MIC value on $S$. aureus and $P$. acnes, reached at concentration of 20\%. The Inhibiton Zone of Formula 1 gel against $S$. aureus and $P$. acnes were $3.83 \pm 0.76 \mathrm{~mm}$ and $1.83 \pm 0.28 \mathrm{~mm}$ repectively, Inhibition Zone of Formula 2 gel against $S$. aureus and $P$. acnes were $6.83 \pm 0.28 \mathrm{~mm}$ and $2.83 \pm 0.57 \mathrm{~mm}$ respectively. The Inhibition Zone of Formula 3 agaisnt $S$. aureus and $P$. acnes were $9.33 \pm 0.57$ and $3.00 \pm 0.5$ respectively. From this study, it can be concluded that the Formula 3 gel containing 30\% mango leaf extract was the most effective formula against $\mathrm{S}$. aureus with the highest Inhibition Zone of $9.33 \mathrm{~mm}$.

Keywords: Arumanis mango leaf extract, anti-bacterial gel, Staphylococcus aureus, Propionibacterium acnes

\section{PENDAHULUAN}

Salah satu masalah kulit yang tidak pernah reda adalah terjadinya jerawat, yang merupakan kelainan kulit yang disebabkan oleh produksi sebum yang berlebih, luruhnya keratinosit dan adanya pertumbuhan bakteri penyebab peradangan, diantaranya ialah Staphylococcus epidermis, Staphylococcus aureus dan Propionibacterium acnes (Fissy et al., 2014). Salah satu cara yang dapat dilakukan untuk mengatasi timbulnya jerawat adalah menggunakan sediaan anti jerawat yang dapat menurunkan sebum dan membantu pengelupasan sel kulit mati sehingga tidak terjadi terkumpulnya bakteri (Sawarkar et al., 2010). Salah satu jenis tanaman yang memililiki potensi sebagai obat jerawat adalah daun Mangga. Ekstrak daun mangga dilaporkan memiliki kandungan senyawa alkaloid, fitosterol, resin, fenol, tannin, flavonoid, saponin dan terdapat kandungan senyawa mangiferan yaitu golongan xanton yang dapat digunakan sebagai senyawa antimikroba
(Somkuwar, 2013; Wauthoz et al., 2007).

Dilaporkan Rahayu (2015) sediaan gel antiseptik tangan yang mengandung ekstrak daun mangga arumanis mampu memberikan efek menurunkan jumlah bakteri S. aureus. Novi et al. (2020) menyatakan aktivitas antibakteri ekstrak etanol $96 \%$ daun mangga arumanis Indonesia menunjukkan aktivitas penghambatan paling kuat terhadap $S$. aureus dengan KHM $40 \%$ dan lebar daerah hambat 3,60 mm pada konsentrasi 40\%. Khaerunissa, et al. (2019) juga menyatakan bahwa ekstrak etanol $60 \%$ daun mangga arumanis dengan metode ekstraksi MAE pada konsentrasi $40 \%$ dapat menghambat pertumbuhan $P$. acnes dan $S$. aureus dengan masing-masing LDH 3,6 mm. Dilaporkan Taddaow et al. (2018), daun tiga jenis mangga di Thailand yaitu Keaw morakot, Nam Doc Mai dan Mahajanaka memiliki aktivitas antibakteri terhadap bakteri yang menginduksi jerawat. Tidak hanya daunnya, dilaporkan Warrapan et al. (2018) bahwa ekstrak biji $M$. indica 
mentah juga tidak hanya efektif sebagai anti bakteri pemicu jerawat terutama $P$. Acnes, tetapi juga memberikan efek antioksidan dan anti-inflamasi. Dinyatakan juga bahwa fraksi etanol ekstrak biji mangga menunjukkan efek antimikroba terkuat terhadap $P$. acnes dengan konsentrasi hambat minimum dan konsentrasi bakterisida minimum masingmasing $1,56 \mathrm{mg} / \mathrm{mL}$ dan $12,50 \mathrm{mg} / \mathrm{mL}$. Efek bakterisida terhadap $P$. acnes dari ekstrak ini dapat diamati setelah 3 jam inkubasi.

Banyak bentuk sediaan farmasi yang dapat dibuat dari senyawa aktif tumbuhan sebagai obat jerawat, namun dilaporkan bahwa pengobatan jerawat menggunakan sediaan gel lebih baik daripada sediaan krim karena pada sediaan gel mudah dibersihkan dari permukaan kulit yang disebabkan oleh pelarut yang polar dan gel tidak mengandung minyak yang dapat memperparah keadaan jerawat (Sasanti et al, 2012).

Gel merupakan sediaan semipadat yang jernih, tembus cahaya dan mengandung zat aktif, merupakan dispersi koloid mempunyai kekuatan yang disebabkan oleh jaringan yang saling berikatan pada fase terdispersi (Ansel, 1989). Gel adalah sediaan yang memiliki karakteristik transparan dan jernih dan memiliki struktur resisten terhadap perubahan lingkungan dan mempunyai aliran viskoelastik (Ismail, 2013). Keuntungan gel diantaranya ialah tidak lengket, kandungan air dalam gel tinggi sehingga jumlah air yang banyak dapat menghidrasi lapisan tanduk dan terjadi perubahan permeabilitas jaringan tanduk menjadi lebih permeable terhadap bahan aktif yang dapat meningkatkan permeases bahan aktif (Lieberman, 1997).

Berdasarkan latar belakang tersebut, maka perlu dilakukan inovasi baru untuk obat antijerawat menggunakan bahan alam, yaitu pembuatan gel anti jerawat dengan bahan aktif dari ekstrak daun mangga arumanis. Sediaan gel anti jerawat tersebut akan diuji daya antibakterinya terhadap bakteri penyebab jerawat yaitu $S$. aureus dan P. acnes, dengan demikian akan didapatkan obat jerawat berapa gel dengan bahan aktif ekstrak daun mangga arumanis. Tujuan penelitian ini ialah membuat formulasi gel ekstrak daun mangga arumanis yang memenuhi standar mutu dan uji efektifitas sediaan gel ekstrak daun mangga tersebut pada bakteri $S$. aureus dan P. acnes. Adapun hipotesis yang yang diajukan dalam penelitian ini adalah formula gel ekstrak daun mangga arumanis dapat digunakan sebagai gel anti jerawat.

\section{BAHAN DAN ALAT}

Bahan yang digunakan adalah daun helai ke-4 sampai ke 7 mangga arumanis (Mangifera indica L.) di wilayah Bogor, biakan bakteri $S$. aureus dan $P$. acnes, 1,3 propanediol $\left(\right.$ Merck $\left.^{\circledR}\right)$, acnol gel, amil alcohol, aquadest, asam klorida $(\mathrm{HCl})$, asam klorida $2 \mathrm{~N}$, , besi (III) klorida, Carbopol ultrez, DMSO, etanol 70\%, fenoksietanol, gelatin, larutan dapar $\mathrm{pH}$, media Brain Heart Infusion, media Trypticase Soy Agar, Natrium Clorida fisiologis, Natrium Clorida, pereaksi alkaloid (Dragendroff, Mayer dan Bouchardat), serbuk Magnesium, trietanolamin.

Alat-alat yang digunakan meliputi autoklaf, ayakan mesh 30, blender, maserator, bunsen, cawan petri, cawan uap, disentrifugasi, hot plate, kaca arloji, kain batis, kapas kasa, kertas saring, krus silikat, labu ukur, laminar air flow cabinet, mistar, mixer, mortar, ose, oven (Bima Jaya ${ }^{\circledR}$ ), pH-meter, pinset, pipet ukur, rotary evaporator, spatel, stamper, 
tanur $\left(N e y^{\circledR}\right)$, timbangan analitik $\left(A n d^{\circledR}\right)$, timbangan digital (Mettler Toledo), viscometer Brookfield (DV1-Prime ${ }^{\circledR}$ ), vortex.

\section{METODE KERJA}

Daun mangga arumanis yang telah terkumpul dideterminasi di Herbarium
Bidang Botani, Lembaga Ilmu Pengetahuan Indonesia (LIPI), Bogor. Daun mangga yang digunakan $465 \mathrm{~g}$ di potong ukuran $2-3 \mathrm{~cm}$, dikeringkan selama 3 hari dalam oven pada suhu $40^{\circ} \mathrm{C}$ dan dibuat simplisia serbuk. Selanjutnya dihitung rendemennya dengan persamaan 1 (DepKes RI, 1995).

$$
\text { Rendemen Serbuk }=\frac{\text { Bobot serbuk }}{\text { Bobot simplisia kering }} \times 100 \% .
$$

Ekstraksi dilakukan dengan maserasi menggunakan pelarut etanol $70 \%$ (1:10). Sebanyak 600g serbuk daun mangga dimasukkan ke dalam maserator dengan pelarut etanol $70 \%$ sebanyak $2000 \mathrm{~mL}$, direndam selama 6 jam sambil sesekali diaduk, didiamkan 18 jam kemudian disaring dan dipisahkan dengan filtratnya. Dengan cara yang sama, ampas hasil ekstraksi diremaserasi kembali dengan etanol $70 \%$ sebanyak $2000 \mathrm{~mL}$, demikian seterusnya sampai maserasi ke tiga menghabiskan $6000 \mathrm{~mL}$ pelarut. Selanjutnya semua filtrat dikentalkan dengan rotary evaporator. Selanjutnya rendemen ekstrak yang dihasilkan dihitung rendemenya dengan persamaan 2 (DepKes RI, 1995).

$$
\text { Rendemen Ekstrak }=\frac{\text { Bobot ekstrak yang diperoleh }}{\text { Bobot simplisia yang diekstraksi }} \times 100 \%
$$

Ekstrak yang diperoleh selanjutnya dilakukan karakterisasi untuk kadar air, kadar abu dan uji organoleptiknya. Penetapan kadar air dan kadar abu dilakukan dengan metode gravimetri (DepKes, 2008 dan DepKes, 2000), dan masing-masing dilakukan secara duplo.
Perhitungan kadar air dilakukan dengan persamaan 3, dan penetapan kadar abu dilakukan dengan persamaan 4 .

Kadar Air $=\frac{\text { Bobot serbuk simplisia akhir }}{\text { Bobot simplisia awal }} \times 100 \%$.

Kadar Abu $=\frac{\text { Bobot abu hasil pembakaran }}{\text { Bobot simplisia yang dibakar }} \times 100 \%$

Selanjutnya ekstrak daun mangga yang didapatkan dilakukan scrining fitokima secara kualitatif untuk flavanoid, tanin, saponin dan alkaloid dengan metode Hanani, 2015). Uji flavanoid dilakukan dengan melarutkan $0,5 \mathrm{~g}$ ekstrak daun mangga ke dalam $5 \mathrm{~mL}$ larutan etanol. Selanjutnya diambil $2 \mathrm{~mL}$ larutan sampel, kemudian ditambahkan $0,1 \mathrm{~g}$ serbuk $\mathrm{Mg}$, dan ditambahkan 10 tetes $\mathrm{HCl}$ pekat, dikocok perlahan. Warna merah atau jingga yang terbentuk menunjukkan adanya flavonoid, jika terjadi warna kuning jingga menunjukkan 
adanya flavon, khalkol, dan auron.

Uji tanin dilakukan dengan melarutkan $0,5 \mathrm{~g}$ ekstrak daun mangga dalam $2 \mathrm{~mL}$ aquadest dalam tabung uji. Kemudian tambahkan dua atau tiga tetes larutan $\mathrm{FeCl}_{3} 1 \%$ ke dalam larutan ekstrak tersebut, jika terbentuk warna biru-hijau terindikasi bahwa ekstrak mengandung tanin (cathecin tanin), sedangkan jika terbentuk biru hitam maka mengandung tanin (garlic tanin).

Uji saponin dilakukan dengan melarutkan $0,5 \mathrm{~g}$ ekstrak daun mangga ke dalam $10 \mathrm{~mL}$ air panas dalam tabung reaksi, dinginkan, dan kocok kuat-kuat selama 10 detik. Terbentuknya buih yang stabil selama tidak kurang dari 1 menit menunjukkan bahwa ekstrak daun mangga positif mengandung saponin.

Uji alkaloid dilakukan dengan menambahkan 1mL HCL dan 9 ML aquadestilata kedalam 0,5 g ekstrak daun mangga dalam tabung reaksi, panaskan di atas penangas air selama 2 menit, didinginkan dan disaring. Filtratnya diteteskan dalam gelas arloji, kemudian di uji dengan 3 pereaksi alkaloid (Bouchardat, Dragendorf dan Mayer). Hasil uji positif ditunjukkan bila terbentuk endapan coklat merah dengan Bouchardat, endapan merah hingga jingga dengan Dragendorf dan endapan putih kekuningan dengan pereaksi Mayer.

\section{Pembuatan Media}

Media yang digunakan adalah Trypticase Soy Agar (TSA) untuk bakteri $S$. aureus dan Brain Heart Infusion (BHI) untuk $P$. acnes. Pembuatan untuk uji KHM, dibuat 1 liter media masingmasing menggunakan $40 \mathrm{~g}$ serbuk TSA dan $47 \mathrm{~g}$ BHI. Media disterilkan dengan autoclave pada suhu $121^{\circ} \mathrm{C}$ selama 15 menit. Setelah suhu media turun, dalam laminair air flow cabinet media dituangkan dalam cawan Petri dengan volune $20 \mathrm{~mL}$ setiap cawan, biarkan membeku dan simpan sampai siap digunakan. Selanjutnya media disimpan dalam inkubator selama 24 jam pada suhu $24^{\circ} \mathrm{C}$ untuk menguji sterilitasnya (Adrianto, 2012).

\section{Uji Aktivitas Antibakteri}

Pengujian aktivitas antibakteri diawali dengan pembuatan suspensi bakteri. Pembuatan suspensi bakteri dilakukan secara aseptis, dengan cara sebanyak 1 ose bakteri diencerkan dengan $\mathrm{NaCl}$ fisiologis $10 \mathrm{ml}$ dalam tabung reaksi steril dan dihomogenkan dengan vortex selama 15detik. Hal ini diulang sampai diperoleh konsentrasi bakteri $10^{6}$. Kekeruhan disetarakan dengan standar $1 \mathrm{Mc}$ Farland setara dengan $3 \times 10^{6}$ sel bakteri/ml (Raihana, 2011).

\section{Uji Konsentrasi Hambat Minimum Ekstrak Daun Mangga}

Pengujian KHM, dilakukan dengan metode dilusi agar, konsentrasi yang digunakan adalah 5\%, 10\%, 15\% dan 20\% yang dilarutkan dalam DMSO. Masingmasing konsentrasi yang diinokulasi kedalam media sebanyak $2 \mathrm{ml}$.

\section{Pembuatan Gel Ekstrak Daun Mangga}

Gel ekstrak daun mangga dibuat dalam 4 formula termasuk basisnya. Konsentrasi ekstrak yang digunakan mengacu pada hasil pengujian KHM dan penelitian Rahayu (2015). Pada formula 0 dibuat tanpa ekstrak dan pada 3 formula (F1; F2; F3) yang lain, dibuat dengan penambahan ekstrak dengan konsentrasi yang berbeda, formula gel dalam penelitian ini disajikan dalam Tabel 1. 
Tabel 1. Formula Gel dan Kosentrasi Ekstrak Daun Manga Arumanis

\begin{tabular}{lcccc}
\hline \multirow{2}{*}{ Jenis bahan } & \multicolumn{4}{c}{ Konsentrasi $(\% \mathrm{~b} / \mathrm{b})$} \\
\cline { 2 - 5 } & FO & F1 & F2 & F3 \\
\hline Ekstrak Daun Mangga & - & 20 & 25 & 30 \\
Carbopol ultrez & 0,5 & 0,5 & 0,5 & 0,5 \\
Trietanolamin & 0,7 & 0,7 & 0,7 & 0,7 \\
Fenoksietanol & 0,9 & 0,9 & 0,9 & 0,9 \\
1,3 propanediol & 9 & 9 & 9 & 9 \\
Air suling (add $100 \mathrm{~mL})$ & 100 & 100 & 100 & 100 \\
\hline
\end{tabular}

Sumber Formulasi basis sediaan: Yanti et al. (2019)

Pembuatan basis gel atau F0 dilakukan dengan cara mendispersi carbopol ultrez dengan menaburkan pada air hangat hingga mengembang selama 30 menit. kemudian ditambah trietanolamin sedikit demi sedikit hingga membentuk massa gel yang transparan (campuran I). Selanjutnya pada 1,3 propanediol ditambahkan fenoksietanol diaduk homogen (campuran II). Kemudian campuran 1 dan 2 dicampur dan tambahkan air suling lalu aduk menggunakan mixer kecepatan 20 rpm selama 3 menit pada suhu ruangan hingga homogen. Selanjutnya pembuatan F1, F2 dan sampai F3 diawali dengan pembuatan basis, kemudian ditambahkan ekstrak daun mangga dengan kosentrasi $20 \%$, $25 \%$ dan $30 \%$ ditambah sisa air suling, aduk hingga homogen. Sediaan yang sudah jadi dimasukkan kedalam wadah tube dan diberi label. Sediaan disimpan pada ruangan yang terlindung dari sinar matahari langsung.

\section{Uji Karakteristik Sediaan Gel}

Uji karakter sediaan gel dilakukan meliputi uji organoleptik, $\mathrm{pH}$, uji viskositas, dan daya sebar. Menurut Djajadisastra et al (2009), uji organoleptik dilakukan dengan warna, bau dan tekstur. Uji homogenitas menggunakan gelas obyek, sediaan gel sebanyak $0,5 \mathrm{~g}$ dioleskan pada gelas obyek dan dinyatakan homogen kalau tidak terihat adanya butiran-butiran kasar. Uji $\mathrm{pH}$ menggunakan $\mathrm{pH}$-meter yang diawali dengan kalibrasi alat menggunakan larutan dapar $\mathrm{pH}$ 4. Nilai $\mathrm{pH}$ dibaca pada skala pH-meter yang ditunjukkan oleh angka pada $\mathrm{pH}$-meter digital (Kaur, et al. 2010). Uji viskositas sediaan gel dilakukan berdasarkan SNI 03-64412000 dengan menggunakan viscometer Brookfield dengan spindle nomor 6. Uji daya sebar dilakukan untuk melihat seberapa besar kemampuan menyebar suatu sediaan diatas permukaan kulit saat pemakaian. Sampel sebanyak 0,5g diletakkan di atas plastic transparan kemudian ditutup dengan plastik transparan dan diberi beban selama 60 detik. Beban yang diberikan masingmasing sebesar 50, 100, 150 dan $200 \mathrm{~g}$. Diameter penyebaran formula yang diambil dihitung rata- rata diameter beberapa sisi (Sinaga, 2015).

Uji daya sebar dilakukan untuk mengetahui kemampuan menyebarnya suatu sediaan gel pada permukaan kulit. Kemampuan daya sebar gel yang baik adalah 5-7 cm (Kaur et al., 2010). Semakin besar diameter sebar. semakin tinggi kecepatan gel menyebar dengan sedikit pengaplikasian sehingga kontak obat dengan permukaan kulit akan meningkat. Sediaan yang memiliki daya sebar yang baik akan lebih disukai karena dapat menyebar dengan mudah di kulit dan nyaman saat digunakan (Wyatt, et al. 2008). 


\section{Pengujian Aktivitas Antibakteri Sediaan Gel}

Pengujian aktivitas antibakteri sediaan gel dilakukan dengan metode difusi sumuran. Pengujian dimulai dengan mengkulturkan bakteri uji $S$. aureus dan $P$. acnes dengan metode pour plate yaitu dengan menuangkan suspensi bakteri tersebut sebanyak $100 \mu \mathrm{L}$ ke dalam cawan petri kemudian ditambahkan medium TSA untuk bakteri $S$. aureus dan BHI untuk bakteri $P$. acnes masing-masing sebanyak $20 \mathrm{ml}$ lalu homogenkan Selanjutnya dibuat 5 buah sumuran pada media agar dengan menggunakan alat pencadang atau lubang tips dengan ukuran $7 \mathrm{~mm}$ (Muljono, et al. 2016). Kemudian setiap lubang di beri label sebagai penanda, F1, F2, F3, kontrol positif dan negatif. Kontrol positif menggunakan acnol gel yang yang beredar di pasaran dan mengandung asam salisilat dan tea tree oil yang berfungsi sebagai anti jerawat, dan kontrol negatif yang digunakan adalah basis gel.

Kemudian setiap lubang yang telah diberi label dimasukkan 50mg sediaan gel F0, F1, F2 dan F3, kontrol positif dan kontrol negatif. Percobaan dilakukan dengan 3 kali ulangan, selanjutnya diinkubasi selama 1x24 jam pada suhu $37^{\circ} \mathrm{C}$, L terbentuk pada media sekitar sumuran (Misna dan Diana., 2016). Nilai LDH dihitung dengan cara mengukur diameter LDH yang dihasilkan dikurangi diameter sumuran $(7 \mathrm{~mm})$ dibagi dua. Selanjutnya menurut Bonev, et al., (2008), nilai respon kekuatan daya antibakteri dibagi menjadi empat kategori yaitu lemah $(<5 \mathrm{~mm})$, sedang $(5-$ $10 \mathrm{~mm})$, kuat $(10-20 \mathrm{~mm})$, dan sangat kuat kuat (> $20 \mathrm{~mm})$. Rancangan percobaan yang digunakan adalah rancangan Acak Lengkap dengan 5 kali ulangan.

\section{HASIL DAN PEMBAHASAN}

Dari 4658g daun mangga yang digunakan menghasilkan serbuk simplisia sejumlah $1745,2 \mathrm{~g}$ dengan randemen 37,47\%, Hasil karakterisasi serbuk simplisia daun disajikan dalam Tabel 2.

Tabel 2. Hasil Karakterisasi Simplisia Serbuk Daun Mangga Arumanis

\begin{tabular}{|c|c|c|c|c|c|c|c|c|}
\hline Jenis & & Kadar & $\operatorname{ir}(\%)$ & Kadar $A$ & ou (\%) & & & \\
\hline $\begin{array}{l}\text { Bahan } \\
\text { Tanaman }\end{array}$ & $(\%)$ & Terukur & Syarat & Terukur & Syarat & Rasa & $\mathrm{Bau}$ & Warna \\
\hline $\begin{array}{l}\text { Daun } \\
\text { mangga }\end{array}$ & 37,47 & 6,33 & $<10$ & 11.81 & $<12$ & pahit & $\begin{array}{c}\text { Khas } \\
\text { aromatik }\end{array}$ & $\begin{array}{l}\text { Hijau } \\
\text { pekat }\end{array}$ \\
\hline
\end{tabular}

Hasil perhitungan kadar air serbuk simplisia adalah 6,33\%, menurut DepKes RI (2000) hasil hasilnya memenuhi syarat karena kadar air kurang dari $10 \%$. Hasil penetapan kadar abu adalah $11,81 \%$, hasil ini memenuhi syarat karena tidak lebih dari $12 \%$ dan tidak lebih dari 5\% untuk syarat kadar abu ekstrak kental (DepKes RI, 2000).

\section{Hasil Ekstraksi Daun Mangga Arumanis}

Hasil ekstraksi dari $600 \mathrm{~g}$ serbuk simplisia daun mangga menghasilkan 112,5 g ekstrak, sehingga randemen yang didapat $18,75 \%$. Hasil yang diperoleh tidak berbeda jauh dari hasil penelitian Rahayu (2015) yaitu sebesar 18,2\%. Karakterisasi ekstrak daun mangga yang dihasilkan disajikan dalam Tabel 3 
Tabel 3. Hasil Karakterisasi Ekstrak Daun Mangga Arumanis

\begin{tabular}{|c|c|c|c|c|c|c|c|c|}
\hline Jenis & & Kadar & $r(\%)$ & Kadar $A$ & pu (\%) & & & \\
\hline $\begin{array}{l}\text { Bahan } \\
\text { Tanaman }\end{array}$ & $\begin{array}{l}\text { Kendemen } \\
(\%)\end{array}$ & Terukur & Syarat & Terukur & Syarat & $\begin{array}{l}\text { Bentuk } \\
\text { fisik }\end{array}$ & $\mathrm{Bau}$ & warna \\
\hline $\begin{array}{l}\text { Daun } \\
\text { mangga }\end{array}$ & 18,75 & 9,75 & $<10$ & 4,74 & $<5$ & kental & $\begin{array}{c}\text { Khas } \\
\text { aromatik }\end{array}$ & $\begin{array}{l}\text { Hijau } \\
\text { pekat }\end{array}$ \\
\hline
\end{tabular}

Hasil skrining fitokimia mengandung senyawa flavonoid, saponin, menunjukkan bahwa baik serbuk tannin juga mengandung klorofil yang simplisia maupun ekstraknya membuat warna hijau pada ekstrak. mengandung senyawa alkaloid, flavanoid, Hasil uji skrining fitokimia serbuk dan saponin dan tanin. Menurut penelitian ekstrak disajikan dalam Tabel 4. ekstrak etanol daun mangga selain

Tabel 4. Hasil Skrining Fitokimia Serbuk Simplisia dan Ekstrak Daun Mangga

\begin{tabular}{lcccc}
\hline \multirow{2}{*}{ Jenis bahan } & \multicolumn{4}{c}{ Senyawa Kimia } \\
\cline { 2 - 5 } & Alkaloid & Flavonoid & Saponin & Tanin \\
\hline Simplisia Serbuk & + & + & + & + \\
Ekstrak Daun & + & + & + & + \\
\hline$+=$ Terdeteksi & & & &
\end{tabular}

\section{Hasil Uji Konsentrasi Hambat Minimum Ekstrak Daun Mangga Arumanis}

Hasil pengujian KHM ekstrak terhadap bakteri $S$. aureus dan P. acnes menunjukkan bahwa kedua bakteri yang diuji mempunyai KHM yang sama yaitu $20 \%$. Oleh karena konsentrasi yang akan digunakan dalam pembuatan gel adalah konsentrasi $20 \%, 25 \%$ dan $30 \%$.

\section{Hasil Sediaan Gel Ekstrak Daun Mangga Arumanis}

Gel formula F1, F2 dan F3 memiliki warna coklat transparan sampai coklat pekat dan memiliki aroma khas daun mangga arumanis. Perbedaan warna dipengaruhi oleh konsentrasi ekstrak daun mangga arumanis yang ditambahkan. Hasil sediaan gel ekstrak daun mangga arumanis dapat dilihat pada Gambar 1.
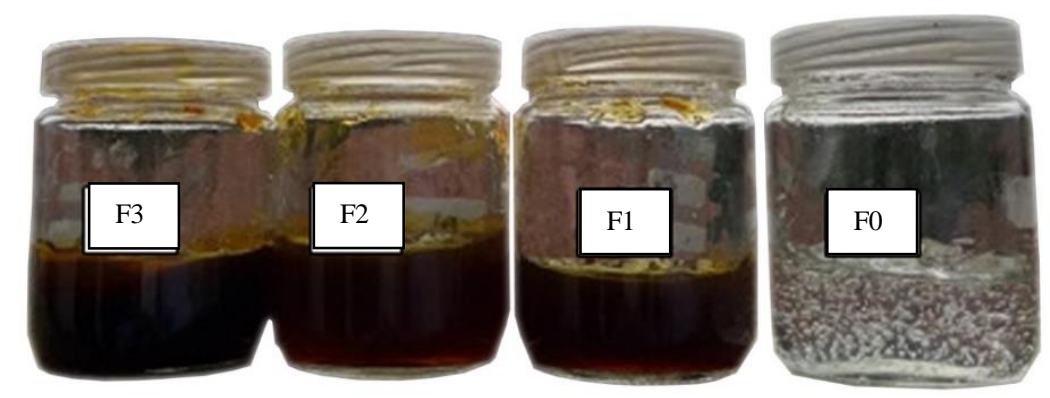

Gambar 1. Sediaan gel ekstrak daun mangga arumanis

Pengujian Karakteristik Sediaan Gel

Pengujian karakteristik sediaan gel berupa parameter fisik diantaranya adalah uji organoleptik (warna, aroma 
dan bentuk sediaan), derajat keasaman $(\mathrm{pH})$, viskositas $(\mathrm{cP})$, uji homogenitas dan uji daya sebar. Hasil pengujian organoleptic, $\mathrm{pH}$ dan viscositas sediaan sediaan gel ekstrak daun mangga disajikan dalam Tabel 5.

Tabel. 5 Hasil Pengujian Organoleptik, pH dan Viscositas Sediaan Gel

\begin{tabular}{lcccc}
\hline \multirow{2}{*}{ Parameter } & \multicolumn{4}{c}{ Formula } \\
\cline { 2 - 5 } & $\mathrm{F} 0$ & $\mathrm{~F} 1$ & $\mathrm{~F} 2$ & $\mathrm{~F} 3$ \\
\hline Warna & bening & coklat & coklat tua & coklat pekat \\
& transparan & transparan & transparan & transparan \\
tidak berbau & khas mangga & khas mangga & khas mangga \\
Aroma & Semi padat & Semi padat & Semi padat & Semi padat \\
Bentuk sediaan & $5,946 \pm 0.07$ & $5,506 \pm 0.10$ & $5,407 \pm 0.22$ & $5,291 \pm 0.01$ \\
Rerata pH & $4416,5 \pm 23,33$ & & $2328 \pm 86,26$ & $2117 \pm 70,71$ \\
Rerata viscositas & & $2742,5 \pm 102,53$ & & \\
$(\mathrm{cps}) \pm \mathrm{SD}$ & & & & \\
& & & & \\
\hline
\end{tabular}

Hasil uji organoleptik menunjukkan warna formula berbeda, semakin tinggi ekstrak yang ditambahkan warnanya menjadi semakin pekat (Gambar 5). Hasil uji pH menunjukkan semua formula sediaan gel ekstrak sesuai $\mathrm{pH}$ kulit 4,5-6,5 sehingga sediaan gel ini aman jika digunakan pada kulit (Nurhakim, 2010). Viskositas semua formula memenuhi persyaratan farmaseutik, yaitu masih dalam rentang antara 2000-4000 cps (Garg, et al. 2002). Hasil menunjukkan bahwa semakin tinggi konsentrasi ekstrak yang digunakan dalam sediaan maka akan semakin kecil nilai viskositas yang didapat.

\section{Hasil Uji Homogenitas}

Hasil uji homogenitas menunjukkan semua formula gel ekstrak daun mangga tidak terdapat adanya partikel padat dalam gel. Hal ini menunjukkan bahwa kandungan bahan didalam sediaan gel tercampur homogen. Hasil uji homogenitas sediaan disajikan dalam Gambar 2.

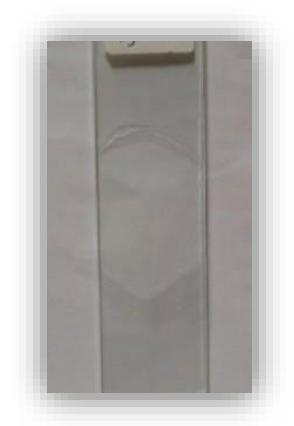

Formula 0

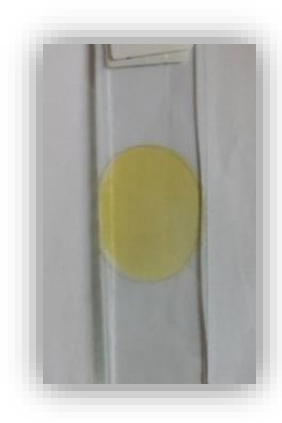

Formula 1

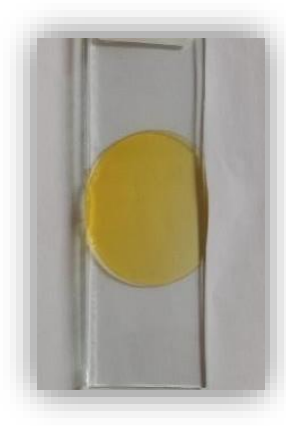

Formula 2

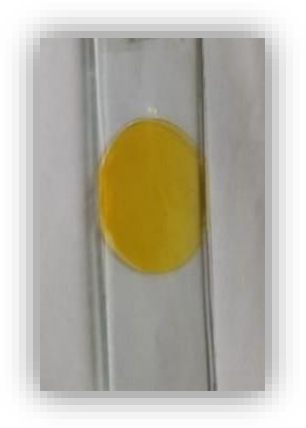

Formula 3

Gambar 2. Hasil uji homogenitas sediaan gel ekstrak daun mangga arumanis

Hasil Uji Antibakteri Sediaan Gel Ekstrak daun Mangga

Hasil sidik ragam menunjukkan formula gel berpengaruh nyata terhadap
LDH bakteri $S$. aureus, hal yang sama juga terjadi pada LDH bakteri $P$. acnes. Rata-rata hasil pengukuran LDH pada formula gel ekstrak daun mangga untuk 
kedua bakteri uji disajikan dalam Tabel 7.

Tabel. 7 Hasil Pengukuran LDH Sediaan Gel Ekstrak Daun Mangga

\begin{tabular}{lcc}
\hline \multirow{2}{*}{ Formula } & \multicolumn{2}{c}{ Rata-rata LDH $(\mathrm{mm}) \pm$ SD } \\
\cline { 2 - 3 } & S. aureus & $P$. acnes \\
\hline Formula 1 & $3,83^{\mathrm{b}} \pm 0,76$ & $1,83^{\mathrm{b}} \pm 0,28$ \\
Formula 2 & $6,83^{\mathrm{c}} \pm 0,28$ & $2,83^{\mathrm{c}} \pm 0,57$ \\
Formula 3 & $9,33^{\mathrm{d}} \pm 0,57$ & $3,00^{\mathrm{c}} \pm 0,50$ \\
Formula K positif & $3,50^{\mathrm{b}} \pm 0,50$ & $4,17^{\mathrm{d}} \pm 0,28$ \\
Formula K negative & $0,00^{\mathrm{a}} \pm 0,00$ & $0,00^{\mathrm{a}} \pm 0,00$ \\
\hline
\end{tabular}

Angka yang diikuti oleh huruf yang sama pada kolom yang sama menunjukan pengaruh yang tidak berbeda nyata menurut uji Duncan's pada $\alpha=0.05$

\section{Hasil uji lanjut Duncan's melebihi kontrol positif.} menunjukkan formula 1 berpengaruh sama dengan kontrol positif terhadap LDH bakteri $S$. aureus (masuk dalam katagori lemah $<5 \mathrm{~mm}$ ). Formula 2 berpengaruh nyata meningkatkan LDH melebihi kontrol positif yaitu $6,83 \mathrm{~mm}$ (masuk katagori sedang) dan paling tinggi LDH adalah formula 3 yaitu $9,33 \mathrm{~mm}$ (sedang). Ini berarti formula 2 dan 3 memiliki respon daya anti bakteri tergolong sedang sampai kuat dan

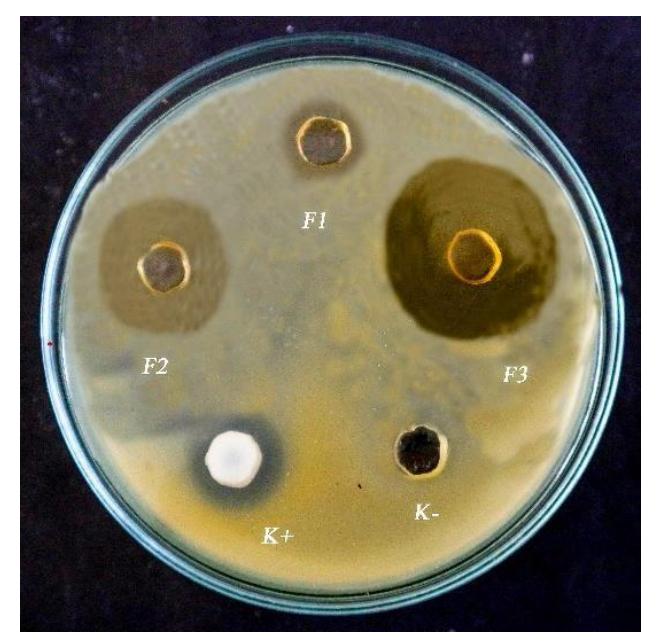

LDH S.aureus
Lebar Daerah Hambat $P$. acnes tidak sebesar pada bakteri S. aureus, hasil uji lanjut Duncan's menunjukkan bahwa formula 1, formula 2 dan formula 3 berpengaruh nyata terhadap LDH bakteri $P$. acnes, tapi masih tergolong katagori lemah sama dengan kontrol positf. Lebar daerah hambat hasil pengujian antibakteri formula gel ekstrak $70 \%$ daun mangga terhahadap bakteri $S$. aureus dan $P$. acnes disajikan dalam Gambar 3.

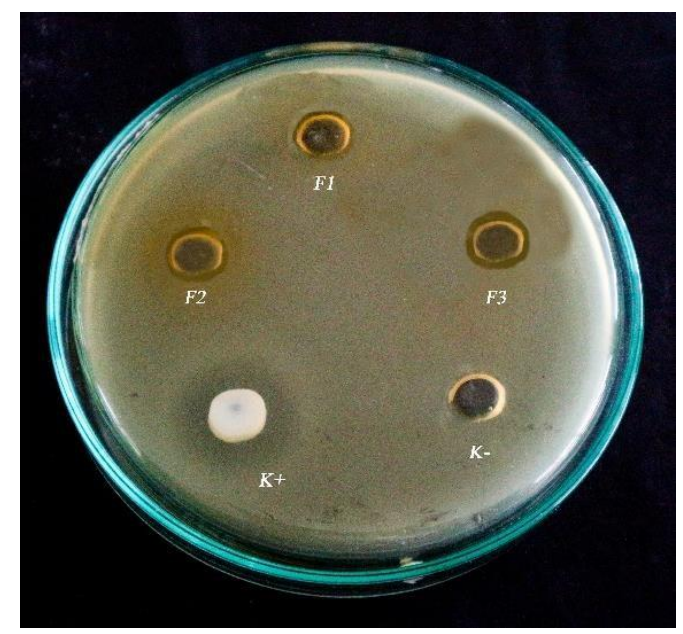

LDH P.acnes

Gambar 3. Hasil uji LDH sediaan gel ekstrak 70\% daun Mangga Arumanis terhadap bakteri $S$. aureus dan $P$. acnes

Aktivitas antibakteri gel ekstrak daun mangga arumanis disebabkan karena memiliki kandungan alkaloid, flavonoid, tannin dan saponin yang berfungsi sebagai senyawa antimikroba yang dapat menghambat pertumbuhan bakteri 
diantaranya Escherichia coli, S. aureus, Klebsiella pneumonia, Listeria monocytogeneses, Campylobacter jejuni, Candida spp, Zygosaccharomyces spp, Fusarium spp, Aspergillus spp, Rhiopus spp dan Penicillium spp (Masibo dan He, 2009). Kandungan terbesar dari ekstrak daun mangga adalah mangiferin yang telah diteliti oleh beberapa peneliti memiliki fungsi lain sebagai antioksidan, analgesik, antidiabetes, antiinflamasi, antitumor, antimikroba, dan peningkat stamina atau daya tahan tubuh (Jutiviboonsuk dan Sardsaengjun, 2010).

Mekanisme kerja saponin sebagai antibakteri yaitu dapat menyebabkan kebocoran protein dan enzim dari dalam sel. Saponin dapat menjadi anti bakteri karena zat aktif permukaannya mirip detergen, akibatnya saponin akan menurunkan tegangan permukaan dinding sel bakteri dan merusak permebialitas membran. Rusaknya membran sel ini sangat mengganggu kelangsungan hidup bakteri (Harborne, 2006).

\section{KESIMPULAN}

Hasil penelitian dapat disimpulkan bahwa pada ketiga formula gel ekstrak daun mangga memenuhi syarat uji evaluasi fisik sediaan yang meliputi uji organoleptik, uji homogenitas, uji $\mathrm{pH}$, uji viskositas dan uji daya sebar. Hasil uji LDH menunjukkan bahwa gel ekstrak daun mangga fomula 3 yang mengandung $30 \%$ ekstrak daun mangga arumanis merupakan formula terbaik dengan uji LDH bakteri $S$. aureus sebesar 9,33 $\mathrm{mm}$.

\section{DAFTAR PUSTAKA}

Adrianto, A.W. 2012. Uji Daya Antibakteri Ekstrak Daun Salam (Eugenia Polyantha Wight) Dalam Pasta Gigi Terhadap Pertumbuhan
Streptococcus mutans. Skripsi. Fakultas Kedokteran Gigi Universitas Jember. Jember.

Ansel, H.C. 1989. Pengantar Bentuk Sedian Farmas, Edisi Keempat, terjemahan Farida Ibrahim. Universitas Indonesia Press. Jakarta.

Bonev, B., Hopper J \& Parisot J. 2008. Principle of assesing bacterial susceptilibility to antibiotics using the agar diffusion method. Journal of Antimicrobial Chemotherapy Nottingham, 61(6):1295-301.

Depkes RI . 1995. Farmakope Indonesia Edisi IV. Direktorat Pengawasan Obat dan Makanan. Jakarta. . 2000. Parameter Standar Umum Ekstrak Tumbuhan Obat Cetakan Pertama. Direktorat Pengawasan Obat dan Makanan. Jakarta.

- 2008. Farmakope Herbal Indonesia Edisi I. Departemen Kesehatan Republik Indonesia. Jakarta.

Djajadisastra, J., Abdul M \& Dessy N.P. 2009. Formulasi gel topikal dari ekstrak Nerii Folium dalam sediaan anti jerawat. Jurnal Farmasi Indonesia, 4 (4).

Fissy, O.N., Sarim R \& Pratiwi L. 2014. Efektivitas gel anti jerawat ekstrak etanol rimpang jahe merah (Zingiber officinale Rosc. Var. rubrum) terhadap $P$. acnes dan Staphylococcus epidermidis. Jurnal Ilmu Kefarmasian Indonesia, 12 (2): 194-201.

Garg, A., Aggarwal D., Garg S \& Sigla A. K. 2002. Spreading of semisolid formulation an update. Pharmaceutical Technology, 202. 84-102.

Harbone, J.B. 2006. Metode Fitokimia, Penuntun Cara Modern 
Menganalisa Tumbuhan. Institut Teknologi Bandung. Bandung

Hanani, E. 2015. Analisis Fitokimia. Penerbit Buku Kedokteran ECG. Jakarta.

Ismail, I. 2013. Formulasi Kosmetik (Produk Perawatan Kulit dan Rambut) Alauddin University Press. Makasar.

Jutiviboonsuk, A \& C. Sardsaengjun. 2010. Mangiferin in leaves of three Thai Mango (Mangifera indica L.). Isan Journal of Pharmaceutical Sciences, 6: 122-129.

Kaur, L.P., Garg R \& Gupta G.D. 2010. Development and evaluation of topical gel of minoxidil from different polymer bases application of alopecia. Int $J$ Pharmacy and Pharm Sci, 2(3): 43-47.

Khaerunissa, R., Prasetyorini, \& Utami F.N. 2019. Uji Aktivitas Antibakteri Ekstrak Daun Mangga Arumanis (Mangifera indica L.) terhadap $P$. acnes dan $S$. aureus. Skripsi. Program Studi Farmasi Fakultas Matematika dan Ilmu Pengetahuan Alam. Universitas Pakuan. Bogor

Lieberman, H. A., Reiger M.M \& Banker G.S. 1997. Pharmaceutical Dosage Forms: Disperse Systems, Vol. 2. Marcell Dekker Inc. New York.

Masibo, M. \& He Q. 2009. In vitro antimicrobial activity and the major polyphenol in leaf extract of mangifera indica L., Malaysian Journal of Microbiology, 5 (2): 7380.

Misna, M \& Diana K. 2016. Aktifitas antibacterial kulit bawang merah (Allium cepa L.) terhadap $S$. aureus. Galenika Journal of Pharmacy, 2(2): 138-144.

Muljono, P., Fatimawali F. \& Manampiring A. E. 2016. Uji aktivitas antibakteri ekstrak daun mayana jantan Coleus atropurpureus (Benth) terhadap pertumbuhan bakteri Streptococcus Sp. dan Pseudomonas Sp. Jurnal ebiomedik(eBm) 4 (1): 164-172.

Novi, F.U., Prasetyorini P., Khaerunissa R., Pramitasari I. \& Herbayani A. 2020. Screening of Mango Leaves (Mangifera Indica L.) Varieties In Indonesia For Antibacterial Activity $S$. aureus. Intl Journal Res. Ayurveda Pharm, 11 (2): 77-80.

Nurhakim, A.S. 2010. Evaluasi Pengaruh Gelling Agent Terhadap Stabilitas Fisik dan Profil Difusi Sediaan Gel Minyak Biji Jinten Hitam (Nigella sativa Linn). Skripsi. Universitas Islam Negri Syarif Hidayatullah. Jakarta.

Rahayu, R,K. 2015. Formulasi dan uji efektivitas sediaan gel antiseptik tangan mengandung ekstrak etanol daun mangga arumanis (Mangifera indica L.). Prosiding Penelitian SPeSIA Universitas Islam Bandung, 553-561.

Raihana, N. 2011. Profil Kultur Dan Uji Sensitivitas Bakteri Aerob Dari Infeksi Luka Operasi Laparatomi di Bangsal Bedah RSUP DR.M. Djamil Padang. Skripsi.Program Pasca Sarjana Fakultas Farmasi, Universitas Andalas. Padang.

Sasanti, T.J., Wibowo, MS., Fidrianny, I. dan Caroline, S. 2012. Formulasi Gel Ekstrak Air Teh Hijau Dan Penentuan Aktivitas Antibakterinya Terhadap $P$. acnes. Penelitian Gedung LabTek VII, School of Pharmacy Institut Teknologi Bandung. Bandung.

Sawarkar, H.A., Khadabadi S.S., Mankar D.M., Farooqui I.A \& Jagtap N. S. 2010. Development and Biological Evaluation Of Herbal Anti-acne 
Gel. International Journal Of PharmTech Research, 2(3): 20282029.

Sinaga, A. A., Luliana S \& Fahrurroji A. 2015. Antioxidant effectivity test of lotion from methanol extract of red dragon fruit (Hylocereus polyrhizus Britton \& Rose). Pharm Science Res. 02(1): 11-20.

Somkuwar, O., Kamble D \& Vilas A. 2013. Phytochemical screening of ethanolic extract of stem, leaves, flower and seed kernel ff Mangifera indica L., Int $J$ Pharm Bio Sci, 4(2): 383-389.

Khumpook, T., Saenphet S., Tragoolpua $\mathrm{T} \&$ Saenphet S. Antibacterial effects of Thai mango (Mangifera Indica Linn.) leaves against acneinducing bacteria. Sci.Int. (Lahore), 30 (3): 449-453.

Yanti, F. F., Komala O \& Almasyhuri. 2019. Uji Aktivitas Sediaan Gel Ekstrak Daun Binahong (Anredera Cordifolia (Tenora) Steenis) Sebagai Antibakteri Terhadap $P$. acnes Bogor. Skripsi. Program Studi Farmasi, Universitas Pakuan. Bogor.

Wauthoz, N., Balde A. Balde E.S. Van Damme M \& Duez P. 2007. Ethnopharmacology of Mangifera indica L. bark and pharmacological studies of its main cglucosylxanthone, mangiferin. International Journal of Biomedical and Pharmaceutical Sciences, 1(2): 112-119.

Wyatt, E. L., Sutter S. H \& Drake L. A. 2008. Dermatology Pharmacology In The Parmacological Basis of Therapeutics (Hardaman J. G., Limbird, L. E., dan Gilman, A. G. (eds), Gilman's 10th edition). McGraw-Hill. New York.

Poomanee, P., Chaiyana W., Mueller M \& Viernstein H. 2018. In-vitro investigation of anti-acne properties of Mangifera indica kernel extract and its mechanism of action against P. acnes. Journal of the Anaerobe, 52: 64-74. 